\title{
Studi Karakteristik Dan Pengelompokan Jenis Tumbuhan Bawah Pada Areal Pusat Pengendalian Kebakaran Hutan Lindung Di KPHL Kota Sorong
}

\author{
Brandon Tanahitumesseng*, Ponisri*, Lona H. Nanlohy* \\ Fakultas Pertanuan Universitas Muhammadiyah Sorong
}

\begin{abstract}
Penelitian ini bertujuan untuk mengetahui karakteristik dan pengelompokan jenis tumbuhan bawah di areal pusat pengendalian kebakaran hutan lindung di KPHL Kota Sorong. Jenis tumbuhan bawah pada areal Pusat Pengendalian Kebakaran Hutan Lindung di KPHL Kota Sorong ditemukan 8 (delapan) jenis dengan penyebaran paling dominan yaitu 4 jenis tumbuhan bawah adalah Alang-alang (Imperata cylindria) (25), Rumput Cakar Ayam ( Digitaria ciliaris) (23), Sentro (Centrosema pubescens) (18), dan rumput teki (Cyperus rotundus) (15). Sedangkan yang tidak mendominasi yaitu Paku kijang (Phegopteris connectilis) (14) . Putri malu (Mimosa pudica) (11), Rumput pait (Axonopus comperesus) (9), dan Babandotan (Agretum conyzoides) (7). Jenis Tumbuhan bawah pada areal Pusat Pengendalian Kebakaran Hutan Lindung di KPHL Kota Sorong memiliki karakteristik yang berbeda-beda sesuai dengan jenisnya dimana penyebarannya mulai dari 0,5 ha, 0,5-1 ha dan > 1 ha.
\end{abstract}

Kata Kunci: Karakteristik, pengelompokan, tumbuhan bawah,hutan lindung.

\section{PENDAHULUAN}

\section{Latar Belakang}

Tumbuhan bawah adalah

komunitas stratifikasi bawah di permukaan tanah dimana tumbuhan ini umumnya berupa rumput, herba, semak dan perdu rendah. Beberapa jenis vegetasi tumbuhan ini bersifat amanual, biannual atau perennial yang hidup dalam bentuk soliter, berumpun, tegak menjalar dan memanjat, tumbuhan ini banyak hidup pada tempat terbuka, pada tepi jalan, tepi sungai, lahan pertanian dan perkebunan (Aththorick, 2005). Tumbuhan bawah mempunyai batang lembut dan mengandung banyak air. Pokok tumbuhan bawah telah lama di gunakan orang melayu dan china sebagai bahan obat atau penguat tenaga. Tumbuhan bawah merupakan salah satu jenis tumbuhan penyusun hutan yang ukurannya jauh lebih kecil jika dibandingkan dengan semak atau pun pohon yang batangnya basah atau tidak berkayu. Tumbuhan bawah juga memiliki daya saing yang kuat dan adaptasinya yang tinggi terhadap tumbuhan sehingga mampu tumbuh di tempat yang kosong. Tumbuhan bawah secara umum merugikan, namun tumbuhan bawah yang tumbuh di tempat tumbuhnya, apa bila belum mencapai tingkatan kerapatan, penutupan, dan tinggi yang telah di anggap mulai merugikan, adakalanya memberikan manfaat pada tempat tumbuhnya dan kelestarian lingkungan.

\section{Rumusan Masalah}

Rumusan masalah dalam penelitianini adalah :

1. Bagaimana karakteristik jenis tumbuhan bawah di areal pusat pengendalian kebakaran hutan lindung di KPHL Kota Sorong. 
2. Bagaimana pengelompokan jenis tumbuhan bawah pada areal pusat pengendalian kebakaran hutan lindung di KPHL Kota Sorong.

\section{Tujuan Penelitian}

Penelitian ini bertujuan untuk :

1. Mengetahui karakteristik jenis tumbuhan bawah pada areal pusat pengendalian kebakaran hutan lindung di KPHL Kota Sorong.

2. Mengetahui pengelompokan jenis tumbuhan bawah pada areal pusat pengendalian kebakaran hutan lindung di KPHL Kota Sorong.

\section{METODOLOGI PENELITIAN}

\section{Tempat dan Waktu Penelitian}

Penelitian ini akan dilakukan pada areal pusat pengendalian kebakaran hutan lindung Kota Sorong dengan waktu penelitian \pm 1 bulan yaitu mulai bulan Agustus sampai September 2017.

\section{Alat dan Bahan}

Alat yang digunakan antara lain kompas, meteran roll, buku lapangan, tally sheet, kamera digital dan buku identifikasi tumbuhan bawah. Bahan yang digunakan adalah tumbuhan bawah yang terdapat pada areal pusat pengendalian kebakaran hutan lindung Kota Sorong.

\section{Metode Penelitian}

Metode yang digunakan adalah metode explorasi dengan teknik observasi langsung. Untuk pengambilan data tumbuhan bawah dibuat plot sebanyak 10 plot pengamatan dengan ukuran plot $2 \times 2 \mathrm{~m}$, dengan jarak antar plot $5 \mathrm{~m}$. Pengamatan tumbuhan bawah pada semua plot yang dibuat dengan ukuran berdasarkan tingkat penyebaran tumbuhan bawah tersebut pada areal pusat pengendalian kebakaran hutan lindung Kota Sorong.

\section{Prosedur Penelitian}

Prosedur dalam penelitian ini meliputi:

1. Melakukan wawancara secara bebas untuk mendapatkan informasi tumbuhan bawah. Berdasarkan informasi tersebut, dilakukan pengamatan pada setiap plot dengan ukuran yang telah ditentukan.

2. Melakukan pengamatan pada setiap plot yang telah ditentukan

3. Melakukan identifikasi untuk mengetahui semua jenis dan karakteristik tumbuhan bawah.

4. Melakukan pengelompokkan tumbuhan bawah dengan cara penilaian (skoring) menurut Hiebert dan Stubbendieck (1993) yang dimodifikasi oleh Tjitrosoedirdjo (2010), yaitu dengan membuat 10 karakteristik bawah dengan nilai 0-3 poin. Tumbuhan bawah dengan total skor yang besar menunjukkan daya tumbuhan bawah yang besar.

\section{Variabel Penelitian} adalah:

Variabel dalam penelitian ini

1. Komposisi jenis (kerapatan, frekuensi dan indeks nilai penting) tumbuhan bawah di areal pengendalian hutan lindung Kota Sorong

2. Keanekaragaman dari jenis-jenis tumbuhan bawah tersebut.

3. Karateristik dan pengelompokan tumbuhan bawah.

\section{Analisis Data}

Data hasil penelitian dianalisis sesuai dengan masing-masing parameter dan dideskripsi secara kualitatif dan kuantitatif serta disajikan dalam bentuk tabulasi dan gambar (bagan, grafik dan foto). 


\section{Frekuensi dan Kerapatan}

Berdasarkan frekuensi dan kerapatan jenis tumbuhan bawah dihitung menggunakan rumus menurut Indriyanto (2006):

a. Kerapatan Individu atau spesies $=$ Jumlah pohon/luas areal

b. Kerapatan Relative suatu spesies

$$
\mathrm{KR}=\frac{\text { Jumlah individu suatu spesies }}{\text { Jumlah individu semua spesies pohon }} \mathrm{X} 100 \%
$$

c. Frekuensi setiap spesies

$$
\mathrm{F}=\frac{\text { Jumlah titik ditemukannya spesies }}{\text { Jumlah seluruh titik pengukuran }}
$$

d. Frekuensi relative setiap spesies

$$
\mathrm{FR}=\frac{\text { Frekuensi suatu spesies }}{\text { Frekuensi seluruh jenis }} \quad \text { X } 100 \%
$$

Indeks Nilai Penting $=$ Kerapatan relative + frekuensi relative

\section{Keanekaragaman}

\section{Tumbuhan Bawah}

\section{Untuk}

menentukan

keanekaragaman jenis tumbuhan bawah digunakan indeks keanekaragaman jenis (H) dari Shanon dan Wiener (1949) dalam Indriyanto (2006) sebagai berikut:

$$
H=-\sum\left[\frac{n i}{N}\right] \cdot \log \left[\frac{n i}{N}\right]
$$

\section{Keterangan:}

$H=$ Indeks keanekaragaman

$n i=$ Jumlah individu atau nilai penting jenis ke-i $N=$ Jumlah individu total nilai penting seluruh jenis

\section{Karakteristik dan Pengelompokkan Tumbuhan Bawah}

Karakterisasi dan pengelompokkan tumbuhan bawah dan diolah menggunakan kriteria pengolompokkan tumbuhan bawah menurut Hiebert dan Stubbendieck (1993) yang dimodifikasi oleh Tjitrosoedirdjo (2010), yaitu dengan membuat 10 karakteristik tumbuhan bawah dengan nilai 0-3 poin. Tumbuhan bawah dengan total skor yang besar menunjukkan daya tumbuhan bawah yang besar, serta disajikan dalam bentuk tabel dan gambar. 
Tabel 1. Metode Skoring Pengelompokan Tumbuhan Bawah

\begin{tabular}{|c|c|c|}
\hline No & $\begin{array}{rr}\text { Kriteria } \\
\end{array}$ & Skor \\
\hline 1 & $\begin{array}{l}\text { Luas Areal Populasi } \\
\text { a. Kurang dari } 0,5 \text { ha } \\
\text { b. } 0,5-1 \text { ha } \\
\text { c. }>1 \text { ha }\end{array}$ & $\begin{array}{l}1 \\
2 \\
3\end{array}$ \\
\hline 2 & $\begin{array}{l}\text { Tingkat kelimpahan populasi } \\
\text { a. Tersebar } \\
\text { b. Merata } \\
\text { c. Luas dan padat }\end{array}$ & $\begin{array}{l}1 \\
2 \\
3\end{array}$ \\
\hline 3 & $\begin{array}{l}\text { Tingkat dampak visual terhadap lahan } \\
\text { a. Tidak ada dampak visual } \\
\text { b. Sedikit berdampak visual } \\
\text { c. Dampak visual cukup besar }\end{array}$ & $\begin{array}{l}0 \\
1 \\
2\end{array}$ \\
\hline 4 & $\begin{array}{l}\text { Regenerasi vegetative } \\
\text { a. Tidak pertumbuhan setelah penyiangan } \\
\text { b. Mampu tumbuh kembali dari akar atau umbi }\end{array}$ & $\begin{array}{l}0 \\
1 \\
\end{array}$ \\
\hline 5 & $\begin{array}{l}\text { Cara produksi } \\
\text { a. Vegetatif } \\
\text { b. Biji } \\
\text { c. } \text { Vegetatif dan biji }\end{array}$ & $\begin{array}{l}1 \\
2 \\
3\end{array}$ \\
\hline 6 & $\begin{array}{l}\text { Kemampuan penyebaran } \\
\text { a. Berpoternsi kecil untuk penyebaran jauh } \\
\text { b. Berpotensi besar untuk penyebaran jauh }\end{array}$ & $\begin{array}{l}1 \\
2\end{array}$ \\
\hline 7 & $\begin{array}{l}\text { Kemampuan kompetetif } \\
\text { a. Kurang kompetetif } \\
\text { b. } \text { Cukup kempetetif } \\
\text { c. } \text { Sangat kompetetif } \\
\end{array}$ & $\begin{array}{l}1 \\
2 \\
3\end{array}$ \\
\hline 8 & $\begin{array}{l}\text { Senyawa allelopati } \\
\text { a. Tidak memiliki senyawa allelopati } \\
\text { b. Memiliki senyawa allelopati cukup kuat } \\
\text { c. Memiliki senyawa allelopati sangat kuat }\end{array}$ & $\begin{array}{l}0 \\
1 \\
2\end{array}$ \\
\hline 9 & $\begin{array}{l}\text { Pengaruh pada areal } \\
\text { a. Sedikit atau tidak memberi efek pada tanaman asli } \\
\text { b. Menyerang dan mengubah tanaman asli } \\
\text { c. Menyerang dan menggantikan tanaman asli }\end{array}$ & $\begin{array}{l}1 \\
2 \\
3\end{array}$ \\
\hline 10 & $\begin{array}{l}\text { Pengendalian } \\
\text { a. Dapat dilakukan } \\
\text { b. Tidak dapat dilakukan }\end{array}$ & $\begin{array}{l}0 \\
3\end{array}$ \\
\hline
\end{tabular}

\section{HASIL DAN PEMBAHASAN}

\section{Karakteristik Tumbuhan Bawah}

Berdasarkan hasil penelitian di lapangan

pada areal pusat pengendalian kebakaran hutan lindung di KPHL Kota Sorong terdapat 8 jenis tumbuhan bawah,disajikan pada tabel 5 di bawah ini: Tabel 2. 


\section{Median Volume X Nomor 1 Bulan Februari 2018}

Tabel 2. Jenis Tumbuhan Bawah pada Areal Pusat Pengendalian Kebakaran Hutan Lindung Kota Sorong

\begin{tabular}{lllll}
\hline No & $\begin{array}{c}\text { Jenis Tumbuhan } \\
\text { bawah }\end{array}$ & \multicolumn{1}{c}{ Nama Ilmiah } & \multicolumn{1}{c}{ Famili } & Habitus \\
\hline 1 & Putri malu & Mimosa pudica & Leguminaceaea & Perdu \\
2 & Sentro & Centrosema pubescens & Fabaceae & Liana \\
3 & Rumput cakar ayam & Digitaria ciliaris & Poaceae & Rumput \\
4 & Paku kijang & Phegopteris connectilis & Thelypteridaceae & Paku \\
5 & Rumput teki & Cyperus rotundus & Cyperaceae & Rumput \\
6 & Rumput pait & Axonopus comperesus & Cyperaceae & Rumput \\
7 & Alang-alang & Imperata cylindria & Cyperaceae & Rumput \\
8 & Babandotan & Agretum conyzoides & Asteraceae & Rumput \\
\hline
\end{tabular}

Pada Tabel 2 di atas terdapat 8 jenis tumbuhan bawah dari kedelapan jenis tersebut yang paling dominan penyebarannya yaitu 4 jenis tumbuhan bawah Alang-alang (Imperata cylindria), Rumput Cakar Ayam ( Digitaria ciliaris), Sentro (Centrosema pubescens), dan rumput teki (Cyperus rotundus). Sedangkan yang tidak mendominasi yaitu Paku kijang (Phegopteris connectilis). Putri malu (Mimosa pudica), Rumput pait (Axonopus comperesus, dan Babandotan (Agretum conyzoides).

Karakteristik tumbuhan bawah pada areal pusat pengendalian kebakaran hutan lindung KPHL Kota Sorong adalah sebagai berikut:

\section{Putri Malu (Mimosa pudica)}

Putri malu (Mimosa pudica), Rumput pait (Axonopus comperesus, dan Babandotan (Agretum conyzoides). Karakteristik tumbuhan bawah pada areal pusat pengendalian kebakaran hutan lindung KPHL Kota Sorong adalah sebagai berikut: Putri Malu (Mimosa pudica) Putri malu (Mimosa pudica) adalah berbentuk perdu merupakan suku dari polong-polongan mudah dikenali sebab daunnya dapat secara cepat menutup dengan sendirinya apabila tersentuh. Tetapi hal ini bersifat sementara atau beberapa menit kemudian akan pulih kembali seperti semula. Tumbuhan bawah ini memiliki luas areal $<0,5$ ha dengan tingkat kelimpahan tersebar, sehingga tidak ada dampak visual terhadap lahan, mampu tumbuh kembali dari akar atau umbi, bereproduksi secara vegetative dan biji berpotensi kecil untuk penyebaran jauh, cukup kompetetif karena memiliki senyawa allelopati cukup kuat, sedikit atau tidak memberi efek pada tanaman asli dan dapat dikendalikan.

\section{Sentro (Centrosema pubescens)}

Sentro (Centrosema pubescens) merupakan tanaman jenis leguminosa semak asal Amerika Selatan Tropis yang memiliki fungsi sebagai tanaman penutup tanah, tanaman sela, dan pencegah erosi. Batang Sentro panjang dan sering berakar terdapat pada bukunya dimana tiap tangkai berdaun tiga lembar, mempunyai bentuk elips dan ujungnya tajam serta berbulu halus pada permukaannya, dengan bunga berupa tandan berwarna ungu. Mempunyai polong berwarna coklat gelap dengan panjang $12 \mathrm{~cm}$ dan memiliki 20 biji.Centrosema pubescens tumbuhan yang dapat membelit pada tumbuhan lain dapat juga menjalar pada pagar juga bersama-sama dengan 
tumbuhan lain menutupi permukaan tanah. Batang panjang, sering berakar pada bukunya, daun dengan tiga anak daun yang berbentuk telur dengan ujung tajam, berambut, panjangnya $5-12 \mathrm{~cm}$ dan lebar 3-10 cm dengan penyebarannya $>1$ ha..

\section{Rumput Cakar Ayam ( Digitaria ciliaris)}

Rumput Cakar Ayam ( Digitaria ciliaris) tumbuhan bawah ini memiliki luas areal populasi $>1$ ha dengan tingkat kelimpahan populasi luas dan padat, berdampak visual cukup besar terhadap lahan, dan mempunyai kemampuan tumbuh kembali dari akar dan umbi, bereproduksi secara vegetative dan biji sehingga berpotensi besar untuk menyebar jauh, sangat kompetetif dengan zat allelopati yang dimilikinya, menyerang dan menggantikan tanaman atau tumbuhan asli serta sukar dikendalikan

\section{Paku Kijang (Phegopteris connectilis) \\ Paku kijang (Phegopteris} connectilis) tumbuhan bawah ini merupakan karateristik dengan Rhizoma tegak, membentuk seperti batang dengan ental yang tersusun meroset di bagian ujungnya. Daun berwarna hijau dengan panjang 30-40 $\mathrm{cm}$ dengan lebar $15-25 \mathrm{~cm}$, sorus berpasangan pada setiap anak daun, warna sorus coklat, berbentuk sorus bulat dengan penyeban $<0,5$ ha.

\section{Rumput Teki (Cyperus rotundus)}

Batang tumbuh berumpun, tegak hingga $50 \mathrm{~cm}$, berumbi batang, banyak memmbentuk rangkaian umbi dengan stolon, tiap umbi mempunyai beberapa mata tunas, berumur tahunan. Daun berbentuk pita persegi tiga, permukaan licin, mengelompok dekat pangkal batang. Bunga bulir tunggal atau majemuk, mengelompok atau membuka berwarna coklat. Berkembang biak denagan umbi dan biji. Tumbuh di tempat terbuka atau agak terlindung, hingga ketinggian $100 \mathrm{~m}$ dpl. Karateristik tumbuhan bawah ini dengan luas areal populasi antara 0,5-1 ha, dengan tingkat kelimpahan populasi tersebar, sedikit berdampak visual, mampu tumbuh kembali dari akar atau umbi, cara reproduksi secara vegetative dan biji, berpotensi kecil untuk penyebaran jauh, cukup kompetetif, memiliki senyawa allelopati cukup kuat, menyerang dan mengubah tanaman asli serta tidak dapat dikendalikan.

\section{Rumput Pait (Axonopus comperesus)}

Keberadaan jenis tumbuhan bawah ini menunjukkan bahwa karakteristiknya kurang dari 0,5 ha (< 0,5 ha) dengan tingkat kelimpahan tersebar, sehingga tidak ada dampak visual terhadap lahan, tidak ada pertumbuhan setelah penyiangan karena hanya bereproduksi dengan biji dan berpotensi kecil untuk penyebaran jauh, cukup kompetetif karena tidak memiliki senyawa allelopati sehingga sedikit atau tidak member efek paada tanaman asli serta dapat dan mudah dikendalikan.

\section{Alang-alang (Imperata cylindria)}

Memiliki daun yang tajam yang sering menjadi bawah pada lahan pertanian. Rumput ini sering dikenal dengaan nama daerah alalang halalang. Alang-alang dapat berkembang biak dengam cepat, denganbenih-benihnya yang tersebar cepat terbawa angin, atau melalui akar rimpangnya yang dapat cepat menembus tanah yang gembur. Alang-alang ini suka pada tanah-tanah cukup subur, banyak mendapat cahaya matahari hingga agak teduh, dengan kondisi yang agak lembap atau kering. Pada tanah-tanah yang basah/berair atau 
terendam, senantiasa ternaungi alangalang tidak mau tumbuh. Dimana alangalang ini akan segera menguasai pada daerah hutan yang terbuka dan rusak, bekas perladangan pada daerah kering dan banyak tumbuh di tepi jalan atau pada pinggir hutan.

Berdasarkan hasil penelitian bahwa karakteristik tumbuhan bawah ini memiliki luas areal populasi $>1$ ha dengan tingkat kelimpahan populasi luas dan padat, berdampak visual cukup besar terhadap lahan, mampu tumbuh kembali dari akar dan umbi, bereproduksi secara vegetative dan biji sehingga berpotensi besar untuk menyebar jauh, sangat kompetetif dengan zat allelopati yang sangat kuat, menyerang dan menggantikan tumbuhan asli serta sukar untuk dikendalikan.

\section{Babadotan (Agretum conyzoides)}

Bandotan

(Ageratum

conyzoides) adalah sejenis tumbuhan bawah pada lahan pertanian, yang berasal dari Amerika tropis, tumbuhan ini namanya berdasarkan aromanya yang mengeluarkan bau seperti kambing. Keberadaan jenis tumbuhan bawah ini memiliki luas areal $<0,5$ ha dengan tingkat kelimpahan tersebar, sehingga tidak terjadi dampak visual terhadap lahan, tidak ada pertumbuhan setelah dilakukan penyiangan karena hanya bereproduksi secara vegetative dan berpotensi kecil untuk penyebaran jauh, kurang kompetetif karena tidak memiliki senyawa allelopati sehingga sedikit atau tidak memberi efek pada tumbuhan asli serta dapat mudah dikendalikan.

\section{Pengelompokan Tumbuhan Bawah}

Berdasarkan hasil penelitian di lapangan maka nilai scoring menurut Hiebert dan Stubbendieck (1993) yang dimodifikasi oleh Tjitrosoedirdjo (2010) pengelompokan tumbuhan bawah dapat dilihat pada tabel 3 dibawah ini.

Tabel 3. Pengelompokan Tumbuhan Bawah Berdasarkan Nilai Scoring

\begin{tabular}{|c|c|c|c|c|c|c|c|c|c|}
\hline \multirow{2}{*}{ Kriteria } & \multirow{2}{*}{ Skor } & \multicolumn{8}{|c|}{ Jenis Tumbuhan Invansif } \\
\hline & & 1 & 2 & 3 & 4 & 5 & 6 & 7 & 8 \\
\hline $\begin{array}{l}\text { Luas Areal Populasi } \\
\text { a. Kurang dari } 0,5 \text { ha } \\
\text { b. } 0,5-1 \text { ha } \\
\text { c. }>1 \text { ha }\end{array}$ & $\begin{array}{l}1 \\
2 \\
3\end{array}$ & 1 & 3 & 3 & 1 & 2 & 1 & 3 & 1 \\
\hline $\begin{array}{l}\text { Tingkat kelimpahan populasi } \\
\text { a. Tersebar } \\
\text { b. Merata } \\
\text { c. Luas dan padat }\end{array}$ & $\begin{array}{l}1 \\
2 \\
3\end{array}$ & 1 & 3 & 2 & 1 & 1 & 1 & 3 & 1 \\
\hline $\begin{array}{l}\text { Tingkat dampak visual terhadap } \\
\text { lahan } \\
\text { a. Tidak ada dampak visual } \\
\text { b. Sedikit berdampak visual } \\
\text { c. Dampak visual cukup besar }\end{array}$ & $\begin{array}{l}0 \\
1 \\
2\end{array}$ & 0 & 2 & 2 & 1 & 1 & 0 & 2 & 0 \\
\hline $\begin{array}{l}\text { Regenerasi vegetative } \\
\text { a. Tidak pertumbuhan setelah } \\
\text { penyiangan } \\
\text { b. Mampu tumbuh kembali dari } \\
\text { akar atau umbi }\end{array}$ & $\begin{array}{l}0 \\
1\end{array}$ & 1 & 0 & 1 & 0 & 1 & 1 & 1 & 1 \\
\hline
\end{tabular}




\section{Median Volume X Nomor 1 Bulan Februari 2018}

\begin{tabular}{|c|c|c|c|c|c|c|c|c|c|}
\hline \multirow{2}{*}{ Kriteria } & \multirow{2}{*}{ Skor } & \multicolumn{8}{|c|}{ Jenis Tumbuhan Invansif } \\
\hline & & 1 & 2 & 3 & 4 & 5 & 6 & 7 & 8 \\
\hline \multicolumn{10}{|l|}{ Cara produksi } \\
\hline a. Vegetatif & 1 & \multirow{2}{*}{\multicolumn{3}{|c|}{2}} & & \multirow{2}{*}{\multicolumn{3}{|c|}{2}} & 1 \\
\hline b. Biji & 2 & & & & 2 & & & & \\
\hline c. Vegetatif dan biji & 3 & 3 & & 3 & & 3 & & 3 & \\
\hline \multicolumn{10}{|l|}{ Kemampuan penyebaran } \\
\hline $\begin{array}{l}\text { a. Berpoternsi kecil untuk } \\
\text { penyebaran jauh }\end{array}$ & 1 & 1 & & & & 1 & 1 & & 1 \\
\hline $\begin{array}{l}\text { b. Berpotensi besar } \\
\text { penyebaran jauh }\end{array}$ & 2 & & 2 & 2 & 2 & & & 2 & \\
\hline \multicolumn{10}{|l|}{ Kemampuan kompetetif } \\
\hline a. Kurang kompetetif & 1 & & & & & & & & 1 \\
\hline b. Cukup kempetetif & 2 & 2 & & & & 2 & 2 & & \\
\hline c. Sangat kompetetif & 3 & & 3 & 3 & 3 & & & 3 & \\
\hline \multicolumn{10}{|l|}{ Senyawa allelopati } \\
\hline $\begin{array}{l}\text { a. Tidak memiliki senyawa } \\
\text { allelopati }\end{array}$ & 0 & & 0 & & & & 0 & & 0 \\
\hline $\begin{array}{l}\text { b. Memiliki senyawa allelopati } \\
\text { cukup kuat }\end{array}$ & 1 & 1 & & 1 & 1 & 1 & & & \\
\hline $\begin{array}{l}\text { c. Memiliki senyawa allelopati } \\
\text { sangat kuat }\end{array}$ & 2 & & & & & & & 2 & \\
\hline \multicolumn{10}{|l|}{ Pengaruh pada areal } \\
\hline $\begin{array}{l}\text { a. Sedikit atau tidak member efek } \\
\text { pada tanaman asli }\end{array}$ & 1 & 1 & & & & & 1 & & 1 \\
\hline $\begin{array}{l}\text { b. Menyerang dan mengubah } \\
\text { tanaman asli }\end{array}$ & 2 & & & & & 2 & & & \\
\hline $\begin{array}{l}\text { c. Menyerang dan menggantikan } \\
\text { tanaman asli }\end{array}$ & 3 & & 3 & 3 & 3 & & & 3 & \\
\hline \multicolumn{10}{|l|}{ Pengendalian } \\
\hline a. Dapat dilakukan & 0 & 0 & 0 & & 0 & & 0 & & 0 \\
\hline b. Tidak dapat dilakukan & 3 & & & 3 & & 3 & & 3 & \\
\hline Jumlah & & 11 & 18 & 23 & 14 & 15 & 9 & 25 & 7 \\
\hline
\end{tabular}

Keterangan: $1=$ Putri malu

$$
\begin{aligned}
& 2=\text { Sentro } \\
& 3=\text { Rumput cakar ayam } \\
& 4=\text { Paku Kijang } \\
& 5=\text { Rumput teki }
\end{aligned}
$$

Pada tabel 6 di atas menunjukan bawah nilai skor tertinggi pada family Cyperaceae yaitu spesies Alang-alang (Imperata cylindria) dengan jumlah 25, family Poaceae Digitaria ciliaris dengan jumlah 23, kemudian diikuti selanjutnya oleh family Fabaceae yaitu spesies Centrosema pubescens dengan jumlah 18, famili Cyperaceae rumput

$$
\begin{aligned}
& 6=\text { Rumput pait } \\
& 7=\text { Alang-alang } \\
& 8=\text { Babandotan }
\end{aligned}
$$

teki (Cyperus rotundus) 15 dan family Thelypteridaceae Paku kijang (Phegopteris connectilis). 14 Sedangkan yang tidak mendominasi yaitu family Leguminaceaea yaitu spesies Putri malu (Mimosa pudica) dengan jumlah 11, famili Cyperaceae Rumput pait (Axonopus comperesus) 9, 
dan family asteraceae Babandotan (Agretum conyzoides) dengan jumlah 7.

Hal tersebut menunjukkan bawah spesies Alang-alang (Imperata cylindria) dan Digitaria ciliaris memiliki skor tertinggi, karena memiliki zat allelopati sehingga mempunyai kemampuan untuk menggantikan tumbuhan lain dan dapat beradaptasi pada jenis yang beragam, dengan luas areal lebih dari 1 ha. Tingkat kelimpahannya luas dan padat, dampak visual cukup besar, mampu tumbuh kembali dengan akar dan umbi, berpotensi besar untuk penyebaran yang jauh, dapat berkembang biak dengan bijinya dan umbi sangat kompetetif dan sulit untuk dikendalikan. Menurut pendapat Moenandir (1990) yang mengatakan bahwa zat allelopati merupakan bahan kimia yang dikeluarkan oleh tumbuhan bawah terhadap tumbuhan dan tanaman pokok yang dapat menyebabkan rusaknya morfologi daun yaitu dipenuhi oleh bercak coklat dan putih, serta menyebabkan tinggi tanaman kerdil, dan panjang akar tidak normal. Secara fisik tumbuhan tersebut bersaing dengan cara pemanfaatan ruang dan cahaya . Sedangkan secara kimiawi bersaing dalam pemanfaatn air, nutrisi, gas-gas penting dalam proses allelopati. Persaingan dapat berlangsung bila komponen atau zat yang dibutuhkan oleh bawah atau tumbuhan dan tanaman budidaya berada pada jumlah yang terbatas, jaraknya berdekatan dan bersama-sama dibutuhkan.

Sedangkan untuk jenis spesies Centrosema pubescens memiliki skor 18, karena mempunyai kemampuan untuk menggantikan tumbuhan lain. Tingkat kelimpahanya luas dan padat dan dampak visualnya cukup besar sehingga berpotensi menyebar luas. Rumput teki (Cyperus rotundus) 15, sebab rumput ini bersifat sangat adaptif dan sehingga tumbuhan bawah yang sangat untuk sulit dikendalikan. Sedangkan yang tidak mendominasi adalah family Thelypteridaceae Paku kijang (Phegopteris connectilis). 14 family Leguminaceaea yaitu spesies Putri malu (Mimosa pudica) dengan jumlah 11, famili Cyperaceae Rumput pait (Axonopus comperesus) 9, dan family asteraceae Babandotan (Agretum conyzoides) dengan jumlah 7 menunjukkan dengan penyebaran kurang dari 0,5 ha, tingkat kelimpahan tersebar pada beberapa plot penelitian, tidak ada dampak visual, berpotensi kecil untuk penyebaran jauh, sedikit atau tidak ada efek pada tumbuhan asli, dan dapat dilakukan pengendalian. Tetapi untuk spesies Mimosa pudica memiliki senyawa allelopati cukup kuat, sangat kompetetif, mampu tumbuh kembali dengan akar atau umbi, dapat bereproduksi secara vegetative dan biji dan tidak dapat dikendalikan.

\section{Kesimpulan}

Berdasarkan hasil penilitian dan pembahasan dapat disimpulkan sebagai berikut:

1. Jenis tumbuhan bawah pada areal Pusat Pengendalian Kebakaran Hutan Lindung di KPHL Kota Sorong ditemukan 8 (delapan) jenis dengan penyebaran paling dominan yaitu 4 jenis tumbuhan bawah adalah Alang-alang (Imperata cylindria) (25), Rumput Cakar Ayam ( Digitaria ciliaris) (23), Sentro (Centrosema pubescens) (18), dan rumput teki (Cyperus rotundus) (15). Sedangkan yang tidak mendominasi yaitu Paku kijang (Phegopteris connectilis) (14) . Putri malu (Mimosa pudica) (11), Rumput pait (Axonopus comperesus) (9), dan Babandotan (Agretum conyzoides) (7) 
2. Jenis Tumbuhan bawah pada areal Pusat Pengendalian Kebakaran Hutan Lindung di KPHL Kota Sorong memiliki karakteristik yang berbeda-beda sesuai dengan jenisnya dimana penyebarannya mulai dari 0,5 ha, 0,5-1 ha dan > 1ha.

\section{DAFTAR PUSTAKA.}

Ahthorick, T. A. 2005. Kemiripan Komunitas Tumbuhan Bawah Pada Beberapa Tipe Ekosistem Perkebunan Di Lahan Batu. Jurnal komunikasi Penilitian.
Hiebert, R.D. and J. Stubbendiek. 1993. Handbook for Ranking Exotic Plants for anagement and Control. Natural Resource Report NPS/NRMWRO/NRR-93/08. U.S Departemen of Inferior National Park Service. Denver Colorado. Indriyanto. 2006. Ekologi Hutan. PT Bumi Aksara. Jakarta

Moenandir, J. 1990. Persaingan Tanaman Budidaya dengan Gulma. Penerbit CV. Rajawali Jakarta.

Tjitrosoedirdjo, S. S. 2010. Konsep, Gulma dan Tumbuhan Invansif. Jurnal Gulma dan Tumbuhan Invansif Tropika 2(1): 89-100. 